\title{
Small-Molecule Protein Kinases Inhibitors and the Risk of Fungal Infections
}

\author{
Katie Bechman ${ }^{1}$ (D) James B Galloway ${ }^{1}$ (D) Kevin L Winthrop ${ }^{2}$
}

Published online: 4 December 2019

(C) The Author(s) 2019

\begin{abstract}
Purpose of Review This review discusses fungal infections associated with licenced small-molecule protein kinase inhibitors. For each major drug class, the mechanism of action and targeted pathways and the impact on host defence against fungi are described. Recent Findings Protein kinase inhibitors are successfully used in the treatment of malignancies and immune-mediated diseases, targeting signalling pathways for a broad spectrum of cytokines and growth-stimuli. These agents predispose to fungal infections by the suppression of integral components of the adaptive and innate immune response.

Summary The greatest risk of fungal infections is seen with bruton tyrosine kinase inhibitors, e.g. ibrutinib. Infections are also reported with agents that target mTOR, Janus kinase and break point cluster (Bcr) gene-Abelson (Abl) tyrosine kinase (BCRABL). The type of fungal infection fits mechanistically with the specific pathway targeted. Infections are often disseminated and present soon after the initiation of therapy. The pharmacokinetic profile, possibility of off-target kinase inhibition, and underlying disease pathology contribute to infection risk.
\end{abstract}

Keywords Small-molecule protein kinases inhibitors · BTK inhibitor · mTOR inhibitor - JAK inhibitor - BCR-ABL inhibitor . Fungal infections

\section{Introduction}

Small molecules that inhibit protein kinases are efficacious in the treatment of cancer, targeting specific mutations that drive tumorigenesis. The pathways targeted by these inhibitors are also important in the signalling and interaction of immune cells. Success in oncology, alongside an improved understanding of the inflammatory signalling cascades, has driven their pursuit in the treatment of immune-mediated diseases. Protein kinases inhibitors block the signalling pathways for a broad spectrum of cytokines and growth stimuli. Their downstream

This article is part of the Topical Collection on Epidemiology of Fungal Infections

Katie Bechman

katie.bechman@kcl.ac.uk

1 Centre For Rheumatic Diseases, King's College London, London SE5 9RJ, UK

2 Division of Infectious Diseases, Oregon Health \& Science University, Portland, OR, USA interference in these cascades has the potential to cause significant and unanticipated immune disturbances.

Fungal infections are of interest to physicians prescribing immunosuppressive therapies. Very few fungi are pathogenic in an immunocompetent host, often limited to those that are dimorphic in nature and endemic to certain geographic locations. Opportunistic fungal infections are invasive and can cause considerable morbidity and mortality in the immunocompromised individual. Specific defects in the immune system may provide clues to the risk of an associated opportunistic fungal infection. For example, patients with HIV/AIDS develop infections with pneumocystosis, cryptococcosis, histoplasmosis, and talaromycosis (formerly known as penicilliosis) as CD4 immunity is essential for the long-term control and memory responses to these fungi [1]. Similarly, $\mathrm{TNF} \alpha$ inhibitors are associated heightened risk of granulomatous fungi including histoplasmosis and coccidioidomycosis due to the critical role of TNF- $\alpha$ in granuloma formation [2]. Invasive aspergillosis is associated with suppression of innate immunity, for example, with chemotherapy or corticosteroidinduced neutropenia [3]. Both innate resistance and acquired immunity play some role in the host defence against Candida. Neutrophils are critical for protection against systemic 
infections such as candidaemia, whilst CD4 cells-mediated immunity and the production of interleukin-17 are important for the protection against mucosal infection [4]. Engagement of pattern recognition receptor on macrophages induces the production of multiple cytokines, which in turn activate $\mathrm{T}$ effector responses. The IL-17 pathway appears integral in candida immunity, with upregulation of proinflammatory cytokines and antimicrobial peptides [5]. The IL-12 family also has an established role, IL-12 is important during systemic infection, whilst IL-23 and Th17 responses protect against mucocutaneous involvement [6].

The spectrum of invasive fungal infections observed in patients prescribed small-molecule protein kinases inhibitors reflects their diverse impact on the immune system, driven by the suppression of integral signally pathways that influence a spectrum of adaptive and innate immune responses.

\section{Small-Molecule Protein Kinases Inhibitors}

Protein kinases control cell transcription, proliferation, differentiation, survival, metabolism, movement, and participate in the immune response [7]. These enzymes modify proteins by 80 chemically adding phosphate groups to them 81 (phosphorylation) and are divided into two major classes: those that phosphorylate tyrosine and those that phosphorylate serine and threonine. Mutations, overexpression, or dysregulation of protein kinases play an essential role in the pathogenesis of many illnesses. Over the last 20 years, this family of enzymes has become one of the most important drug targets $[8 \bullet \bullet, 9]$.

The discovery of small-molecule protein kinases inhibitors marked a revolutionary milestone in cellular biology research. In 2001, Imatinib became the first FDA-approved mechanismbased small-molecule kinases inhibitor [7]. There are currently 48 approved agents (Fig. 1), 25 inhibit receptor proteintyrosine kinases, 10 inhibit non-receptor protein-tyrosine kinases, and 13 are directed at protein-serine/threonine protein kinases. Forty-three inhibitors are directed toward malignancies; 37 against solid tumours including lymphomas and 8 against non-solid tumours, e.g. leukaemia's. Seven are directed toward non-malignancies, including transplantation rejections, inflammatory arthritis, ulcerative colitis, polycythemia vera, idiopathic pulmonary fibrosis and glaucoma [8••].

Small-molecule protein kinases inhibitors offer advantages over chemotherapeutics, RNAi agents and immune-targeted biologics. Their specificity results in fewer side effects than cytotoxic chemotherapy, where all cells may be vulnerable. They are small chemical compounds that are easy to synthesize and being nonproteinaceous are orally bioavailable. In inflammatory disorders, these inhibitors interfere with a wide spectrum of cytokines involved in existing and potential inflammatory pathway, overcoming challenges in therapeutic efficacy seen with single cytokine inhibition. However, their use may be accompanied by resistance, caused by overexpression of the target kinase, a receptor mutation or activation of other signalling pathways [10]. They demonstrate a dose-proportional pharmacokinetic profile,

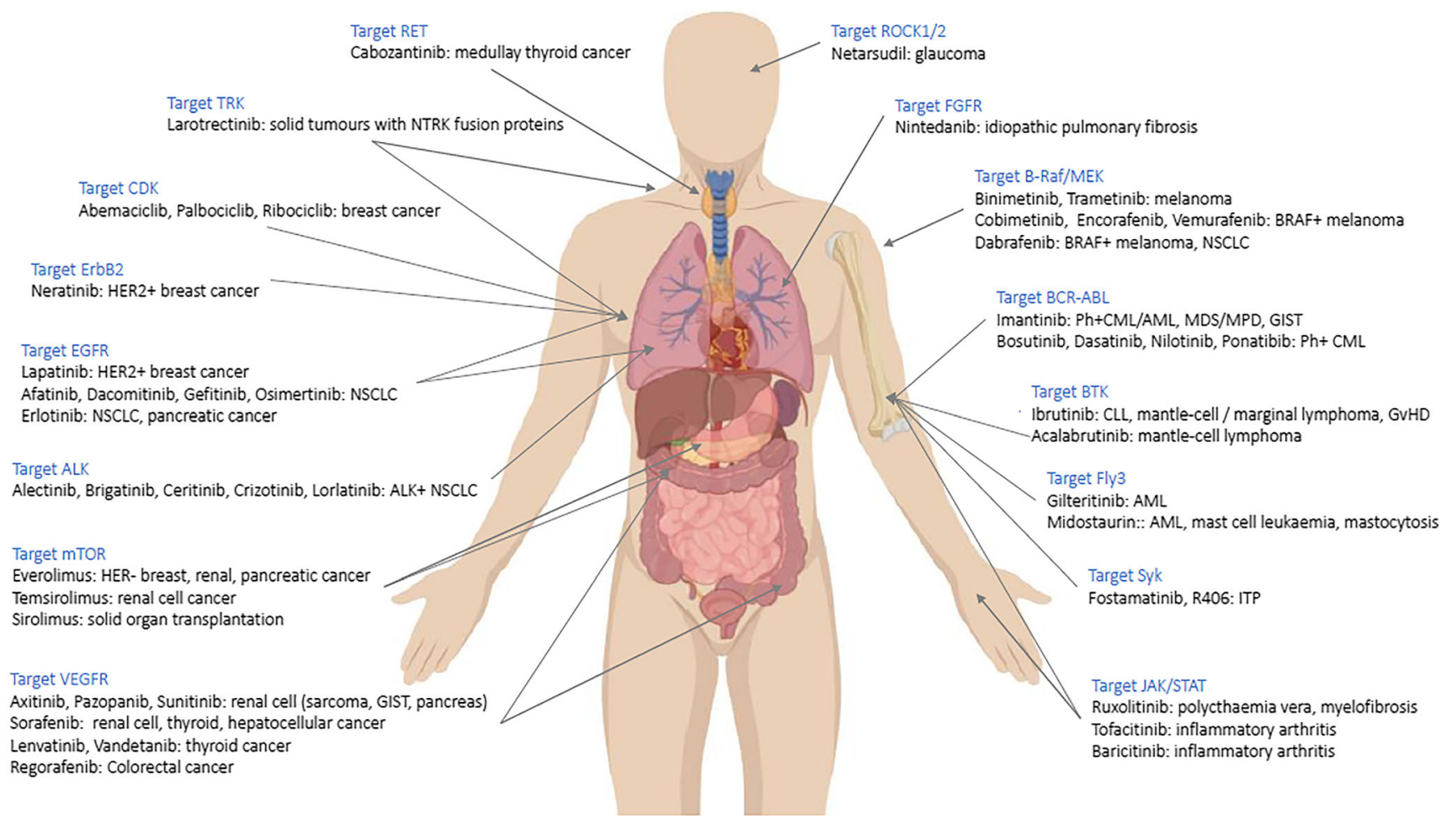

Fig. 1 Primary therapeutic targets of small-molecule protein kinases inhibitors (despite many being multikinase inhibitors) and licenced condition 
with possible off-target kinase inhibition, and are subject to hepatic metabolism, renal clearance and drug interactions, alongside the generation of active metabolites which may exacerbate things further. There is increasing evidence that many of these inhibitors can have a substantial impact on immune function and a subsequent risk of opportunistic infections.

\section{Fungal Infection by Protein Kinase Target}

In this narrative review, we searched the literature using MEDLINE and EMBASE databases to identify publications on fungal infections with small-molecule protein kinases inhibitors. The search included all 48 approved agents as of March 2019. A total of 1101 articles were identified, of which 81 were eligible. A further 17 studies were excluded as they presented limited data on fungal infections, did not classify infections numbers by drug or only presented animal data on fungal infections. In total, 64 studies were eligible for inclusion in our analysis. Of the 48 small-molecule protein kinases inhibitors, only 18 had publications identified in the search.

\section{Bruton tyrosine kinase inhibitor}

Bruton tyrosine kinase (BTK) plays a crucial role in B cell development. Bruton's agammaglobulinemia is an X-linked primary immunodeficiency caused by mutations in BTK. Children with this condition suffer from opportunistic infections in early life. They have normal pre-B cell populations in their bone marrow, but these cells fail to mature and enter the circulation. Ibrutinib is a BTK inhibitor that results in decreased B cell survival (Table 1). Although the prominent effect is on B cells, other haemopoietic cells are affected, including T cells, natural killer cells and macrophages [11]. BTK has emerged as a key player in innate immunity. It is implicated in toll-like receptor (TLR) signalling pathways that regulate macrophage activation and the production of proinflammatory cytokines [12]. It also regulates a key innate inflammatory machinery, the NLRP3 inflammasome [13].

It is likely that fungal infection with BTK inhibitors results from a complex immunodeficiency affecting a broad range of immune cells in the adaptive and innate immune system. CD4 T cell-macrophage crosstalk plays an important role in the host's defence against fungal infections. Increased susceptibility may result from the inhibition of BTK signalling in monocytes and macrophages, impeding chemotaxis, adhesion, transmigration, reactive oxygen species production, cytokine response, and inflammasome activation [14••]. BTK gene knockout mice demonstrate increased mortality from fungal infections, particularly aspergillus and cryptococcus $[15,16]$. Macrophage activation in the immune response against Aspergillus is driven by TLR9 signalling through BTK [17]. Furthermore, BTK inhibitors may have off-target effects on other kinases that affect CD4 T cell function, especially when the drug is given at higher doses.
The greatest number of publications on fungal infections with protein kinase inhibitors was identified with ibrutinib (Table 2). Aspergillosis was the most frequently reported fungal infection. These studies reported that most patients present within a few months of the initiation of ibrutinib therapy, with a high rate of CNS involvement and a low survival rate $[11,18 \bullet \bullet$. Similar findings are noted with other fungal infections presenting soon after starting therapy [19]. One author noted that the early onset of disseminated cryptococcosis might suggest that patients had preceding pulmonary colonization [20]. In general, infections occurred at multiple sites, especially with aspergillus and mucormycosis [21]. There were a similar number of cases reported with ibrutinib monotherapy as combination therapy [19]. Steroid therapy, allogeneic stem cell transplantation, three or greater prior treatments, prolonged neutropenia, diabetes, and liver disease all represented additional risk factors for fungal infections [22-24]. Patients with Pneumocystis jirovecii pneumonia demonstrated normal CD4+ T cell counts and immunoglobulin levels, suggesting that a high level of clinical suspicion may be required to diagnose infections in these patients [25]. Acalabrutinib is a second-generation BTK inhibitor, designed to be more potent and selective than ibrutinib. The number of reported fungal infection is less than that seen with ibrutinib. A large safety analysis of 610 patients on acalabrutinib monotherapy described only 4 fungal infections [26] whilst just 1 case report was identified in the literature, of a patient with a disseminated cryptococcal infection [27].

\section{Mechanistic target of rapamycin inhibitor}

Mechanistic target of rapamycin inhibitor (mTOR) is a serine and threonine protein kinase, identified over 20 years ago as the target of the drug rapamycin (sirolimus), from which mTOR's name derives. It is now recognised that mTOR plays a crucial role in cell growth and proliferation [28]. mTOR inhibitors block signalling of growth factors and nutrients via the phosphoinositide 3-kinase (PI3K)/AKT/mTOR protein cascade (Table 1). Sporadic mutations or deregulation of PI3K and AKT, together with $\mathrm{p} 53$, are some of the most prevalent alterations in human cancer. mTOR inhibitors are used in the treatment of cancers and the prevention of renal allograft rejection. Signalling via mTOR is essential for IL-2 driven T cell proliferation and differentiation via nutrient availability and cytokine/growth factor signalling [29]. Interestingly, blocking mTOR signally leads to a differential development of $\mathrm{T}$ cell subpopulations, some of which inhibit an immune responses whilst others actually promote immunity [29]. Experimental studies suggest mTOR signalling also drives on $\mathrm{B}$ cell differentiation and activation of $\mathrm{B}$ cell differentiation and activation of $\mathrm{B}$ cell and the functioning of antigen-presenting cells, specifically their ability to stimulate $\mathrm{T}$ cell activation [30]. 
Table 1 Small-molecule protein kinases inhibitors, mechanism of action, target disease and drugs

\begin{tabular}{|c|c|c|c|}
\hline Target & Mechanism of action & Diseases & Drugs \\
\hline BTK inhibitor & $\begin{array}{l}\text { Interferes with B cell signalling } \\
\text { cascades via B cell receptor } \\
\text { pathway } \\
\text { - Binding to BTK, prevents key } \\
\text { phosphorylation } \\
\text { - Reduces B Cell differentiation, } \\
\text { proliferation and migration } \\
\text { - Decreasing B cell survival and } \\
\text { anti-tumour activity } \\
\text { Also interferes with TLR signalling, } \\
\text { reducing macrophage activation } \\
\text { [12] and regulates NLRP3 } \\
\text { inflammasome [13] }\end{array}$ & $\begin{array}{l}\text { Leukaemia (chronic lymphocytic } \\
\text { leukaemia) } \\
\text { Lymphoma (mantel cell marginal } \\
\text { zone) }\end{array}$ & $\begin{array}{l}\text { Imatinib } \\
\text { Acalabrutinib }\end{array}$ \\
\hline mTOR inhibitor & $\begin{array}{l}\text { Interferes with signalling of growth } \\
\text { factors and nutrients via the } \\
\text { PI3K/AKT/mTOR protein } \\
\text { cascade [64] } \\
\text { Acts via mTOR complex } 1 \\
\text { - Reduces protein synthesis, } \\
\text { glycolysis, lipogenesis leading to } \\
\text { autophagy } \\
\text { - Reduces angiogenesis, } \\
\text { proliferation and migration } \\
\text { Acts via mTOR complex } 2 \\
\text { - Blocks AKT activation, reducing } \\
\text { proliferation \& induces cell death } \\
\text { (blocks G1/S cell cycle, cell) }\end{array}$ & $\begin{array}{l}\text { Cancer (renal cell carcinoma, breast, } \\
\text { pancreas) } \\
\text { Renal transplant }\end{array}$ & $\begin{array}{l}\text { Everolimus } \\
\text { Temsirolimus } \\
\text { Sirolimus }\end{array}$ \\
\hline JAK inhibitor & $\begin{array}{l}\text { Interferes with signalling via the } \\
\text { JAK-STAT pathway } \\
\text { - Signally requires } 2 \text { associated } \\
\text { JAKs to phosphorylate, } \\
\text { - JAK1 pairs with any of the } 3 \text { JAKs } \\
\text { and signals IFNs, IL-10, IL-6 } \\
\text { - JAK2 signals growth hormones } \\
\text { (EPO, TPO, GM-CSF) } \\
\text { - JAK3 signals } \gamma \text {-chain cytokines } \\
\text { (IL-2, IL-4, IL-7, IL-9, IL-15, } \\
\text { IL-21) } \\
\text { - TYK signals IFN } \alpha \& \beta, \text { IL-12 \& } \\
\text { IL-23 } \\
\text { - Reduces activation of STATs } \\
\text { (transcription factors) which } \\
\text { would lead to gene transcription } \\
\text { [65, 66]. } \\
\text { - Decreasing cytokine driven } \\
\text { activation and function of both } \\
\text { innate and adaptive immune cells }\end{array}$ & $\begin{array}{l}\text { Inflammatory arthritis } \\
\text { Myelofibrosis, polycythemia vera }\end{array}$ & $\begin{array}{l}\text { Tofacitinib } \\
\text { Baricitinib } \\
\text { Ruxolitinib }\end{array}$ \\
\hline $\begin{array}{l}\text { BCR-ABL } \\
\text { inhibitor }\end{array}$ & $\begin{array}{l}\text { Inhibit ABL tyrosine kinase activity, } \\
\text { blocking autophosphorylation } \\
\text { driven by the juxtaposition of } \\
\text { BCR. } \\
\text { Interferes with a number of survival } \\
\text { pathways that are deregulated by } \\
\text { BCR-ABL activation }[46,47] \\
\text { - RAS/RAF/MEK/ERK pathway- } \\
\text { reducing signalling of nuclear } \\
\text { transcription factors which govern } \\
\text { cell cycle control \& thus } \\
\text { decreases cell proliferation } \\
\text { - JAK-STAT pathway-impairing } \\
\text { transcriptional activity via } \\
\text { cytokine \& hormone signalling }\end{array}$ & $\begin{array}{l}\text { Haematological malignancies } \\
\text { (Philadelphia chromosome-positive } \\
\text { chronic myeloid leukaemia, } \\
\text { myelodysplastic syndromes, } \\
\text { myeloproliferative disorder) }\end{array}$ & $\begin{array}{l}\text { Imatinib } \\
\text { Dasatinib } \\
\text { Nilotinib } \\
\text { Ponatinib } \\
\text { Bosutinib }\end{array}$ \\
\hline
\end{tabular}


Table 1 (continued)

\begin{tabular}{|c|c|c|c|}
\hline Target & Mechanism of action & Diseases & Drugs \\
\hline & $\begin{array}{l}\text { - } \mathrm{PI} 3 \mathrm{~K} / \mathrm{AKT} / \mathrm{mTOR} \text { pathway- } \\
\text { resulting in increased apoptosis }\end{array}$ & & \\
\hline
\end{tabular}

mTOR inhibitors predominantly effect mTORC1. Ras-Raf-MEK-ERK pathway also known as the MAPK/ERK pathway

TLR Toll-like receptor; PI3K phosphoinositide 3-kinase; $A K T$ protein kinase B; $M E K$ mitogen-activated protein kinase/extracellular signal-regulated kinase; IFN interferon; IL interleukin; EPO erythropoietin; TPO thrombopoietin; GM-CSF ganulocyte-macrophage colony-stimulating factor

mTOR inhibitors have antifungal activity against Cryptococcus neoformans, Candida and possibly Aspergillus. This is mediated against the fungal homologue TOR kinases proteins, blocking its ability to promote fungal cell proliferation via nutrient-sensing pathways to promote fungal cell proliferation. Rapamycin was initially discovered as antifungal agent. However, the immunosuppressive effects of mTOR inhibitors dominate. The antifungal attributes may confer some protection which could manifest as a lower frequency of infections or a lower risk of dissemination [31].

Our results confirm relatively few cryptococcal or candida infections reported with rapamycin (Table 2). Cryptococcosis in transplant recipients likely resulted from reactivation of latent infection, and the incidence is low compared with other latent infections in transplant recipients [31]. In contrast, $P$. jirovecii pneumonia (PJP) was the most frequently reported fungal infection with mTOR, especially sirolimus. It is recognised that sirolimus-based regimens are a risk factor for PJP [32••]. A large retrospective cohort study of Medicare primary transplant recipients reported 41 events [32••]. There were no data on the proportion of patients treated with PJP prophylaxis. Other smaller studies have reported PJP infection with sirolimus in patients who have not received prophylaxis or occurring after the withdrawal of prophylaxis at 6 months [33]. Sirolimus-induced pneumonitis is a known side effect of sirolimus therapy and may be the underlying mechanism $[32 \bullet \cdot]$. There are fewer data regarding everolimus and temsirolimus. A large meta-analysis of randomised controlled trials data on 1601 patients reported 7 fungal infections, candida being the most commonly report fungi [34]. Aspergillus and P. jirovecii have also been reported. A retrospective review of 12 patients switched from tacrolimus to everolimus maintenance regimen for heart transplantation reported 6 cases of PJP infection, despite completing 6-month post-transplant PJP prophylaxis. These infections occurred on everolimus therapy, several months after withdrawal of prophylaxis. The authors suggested that the high frequency of PJP infection might be attributed to the high everolimus dose and high serum trough concentration [35].

\section{Janus kinase/signal transducers and activators of transcription inhibitor}

The Janus kinase/signal transducers and activators of transcription (JAK-STAT) pathway is regarded as a central communication node for the immune system [36]. It mediates the effect of many different cytokines, including interleukins, interferons and growth factors such as granulocytemacrophage colony-stimulating factors (GM-CSF) (Table 1). Signally via this pathway is critical for host defence and immunoregulation. Mutations in the JAK enzymes are associated with myeloproliferative haematological malignancies, autoimmunity and immunodeficiency syndromes. The effects of JAK inhibitors are influenced by their selectivity for a JAK enzymes subtypes; tofacitinib inhibits JAK1 and JAK3 [37], whilst baricitinib inhibits JAK1 and JAK2 and is considered JAK3 sparing [38]. Ruxolitinib targets JAK1 and JAK2, effecting the signally of growth factors erythropoietin, thrombopoietin and thrombopoietin and GM-CSF.

Cytokine balance plays a pivotal role in adaptive and innate immune defences against fungal infections. JAK inhibition downregulates cytokine signalling, decreasing the activation and infiltration of NK cells and macrophages into infected tissues and impacting subsequent phagocytic activity [39]. IFN- $\gamma$ cytokine secretion generates a proinflammatory and microbicidal environment. In experimental models, resistance to cryptococcosis is associated with IFN- $\gamma$ production, lymphocyte infiltration and macrophage activation [40]. Mice deficient in IFN- $\gamma$ are significantly more susceptible to systemic candida [41], and recent findings have suggested that IFN- $\alpha$ and IFN- $\beta$ may demonstrate an even more significant role than IFN- $\gamma$ in host defence [39]. GM-CSF enhances the antifungal phagocytic activity of neutrophils, with deficient mice susceptible to a wide range of fungal pathogens [39].

There were few fungal infections reported in the literature with ruxolitinib (Table 2). Cryptococcal infection (pulmonary and extrapulmonary) were the most frequently reported fungus. [42]. Infections occurred at various intervals after the initiation of ruxolitinib, and whether the infection risk is dosedependent remains controversial [43]. The number of reported fungal infections were slightly higher with tofacitinib. This might be due to extensive post-marketing surveillance with over 34,000 patient years of follow-up. In this large analysis, only 10 fungal infections were reported [44]. Overall, the commonest reported fungi were Candida, followed by $P$. jirovecii and Cryptococcus. In the RCTs and LTE studies, no cases of endemic mycotic infections (histoplasmosis, coccidioidomycosis and blastomycosis) were observed, but 


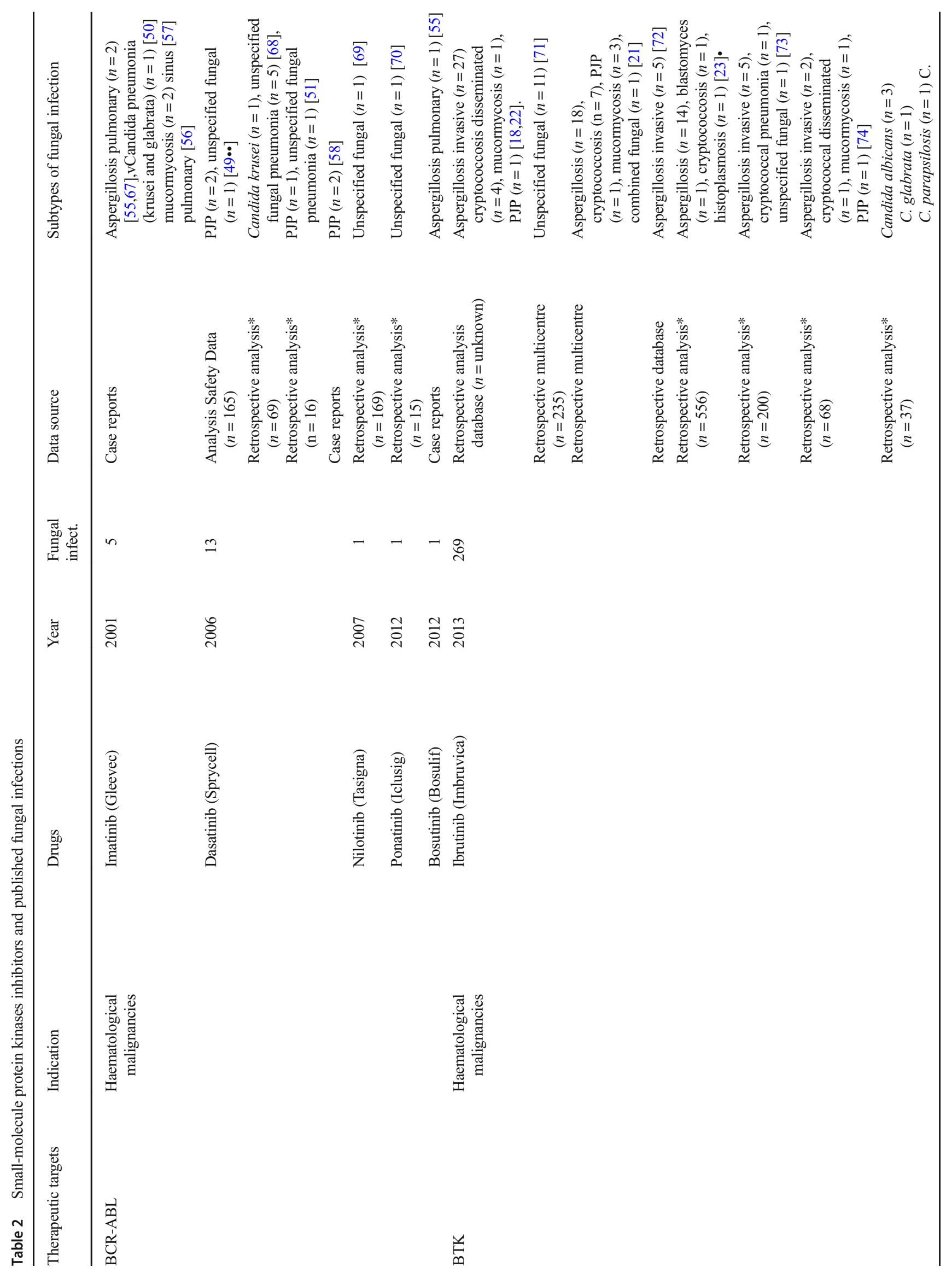




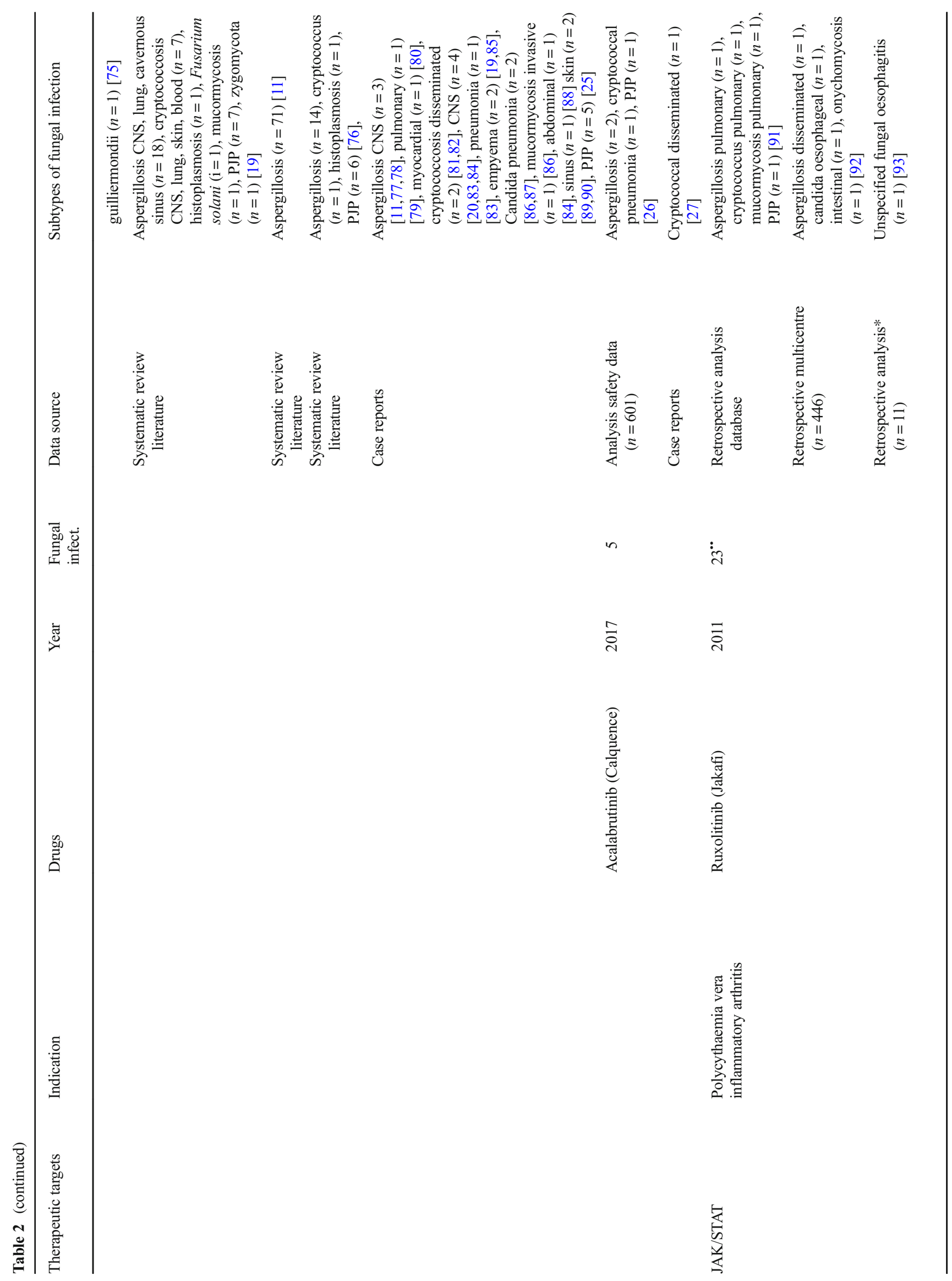




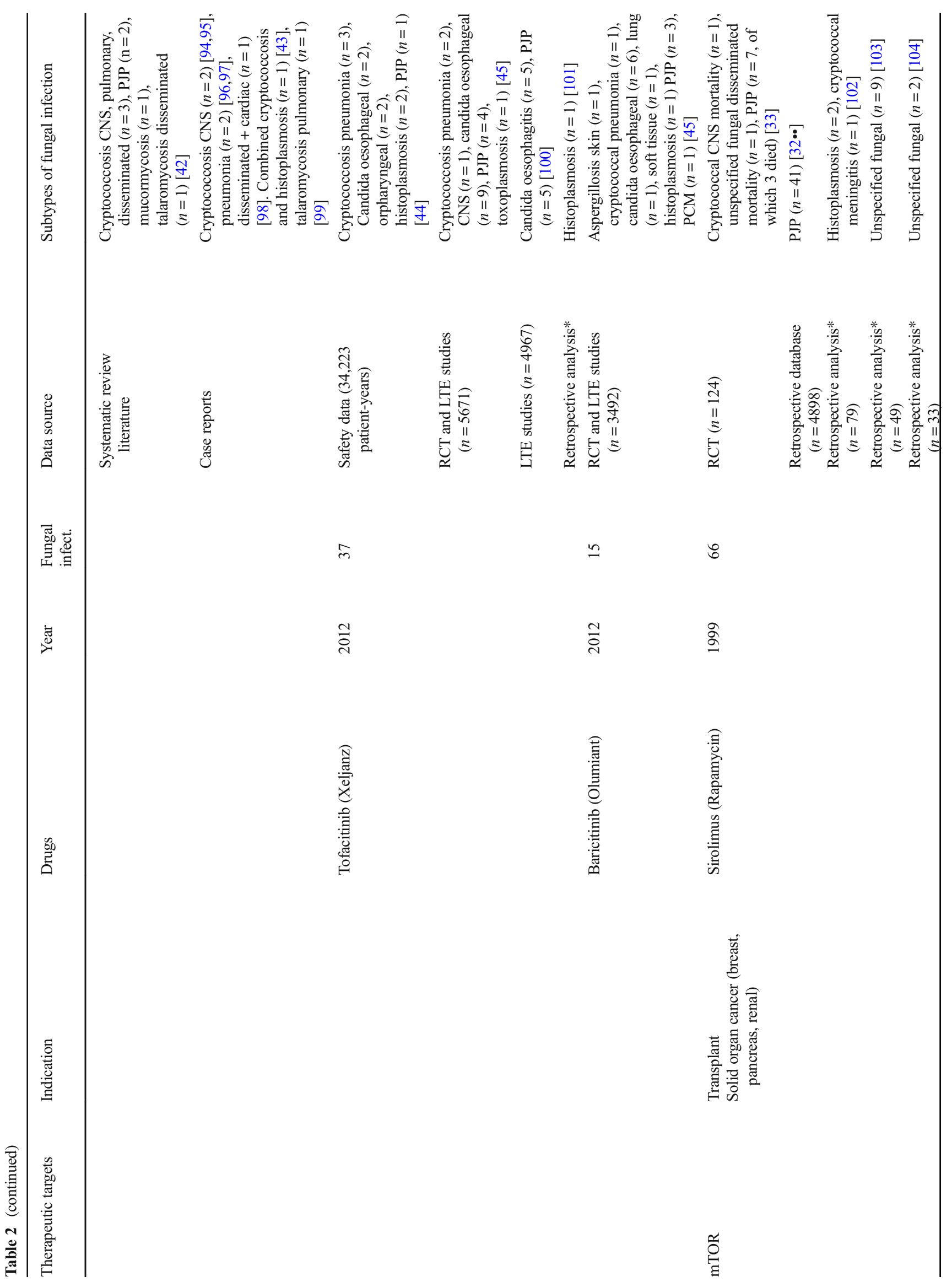




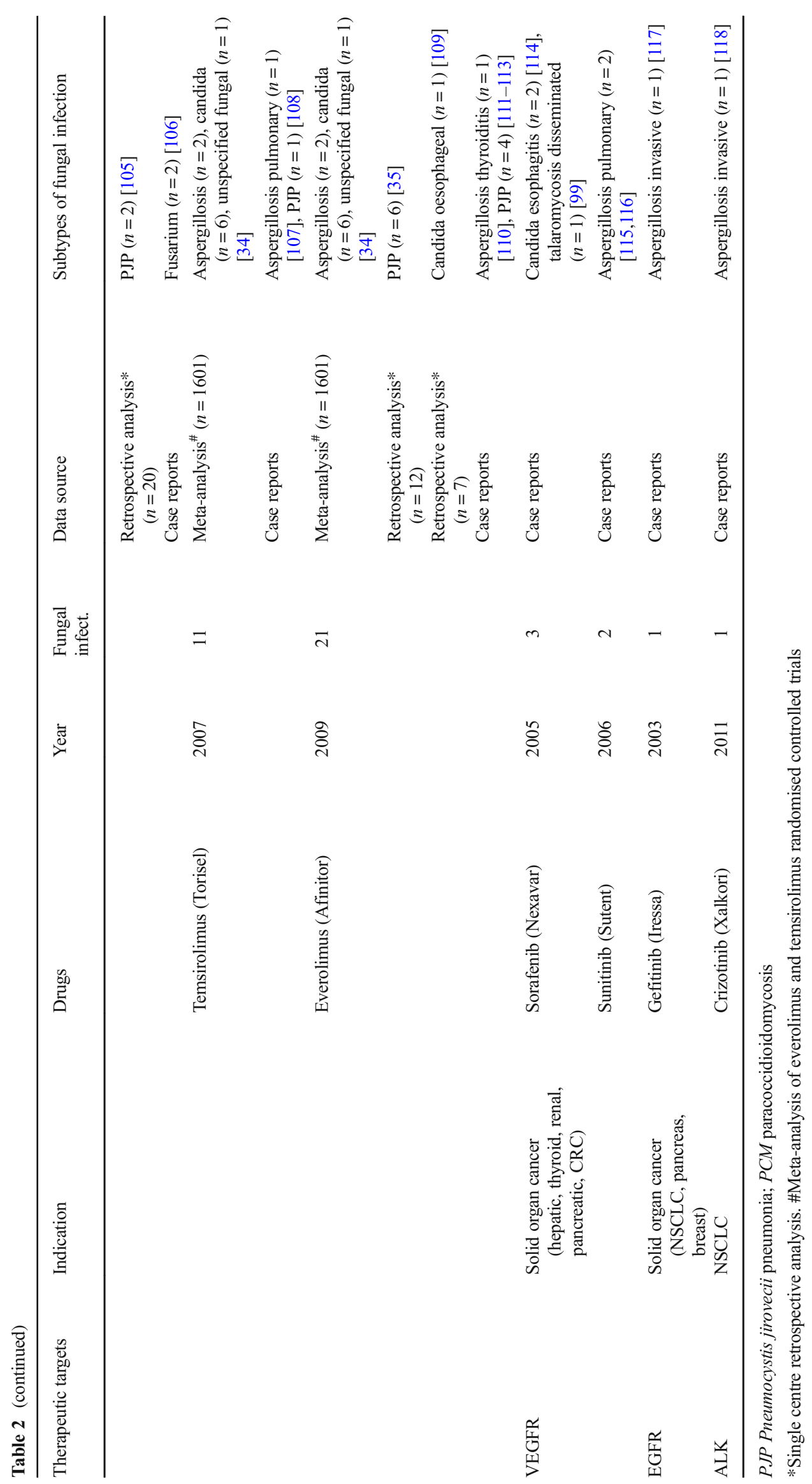


presumably few patients were enrolled from regions where these organisms are endemic [45]. The incidence of opportunistic infections including fungal were greater in patients receiving higher doses or steroid therapy. As seen with ruxolitinib, infections occurred at a variety of time points after starting therapy (range 6-179 weeks) [45]. Few fungal events were reported in the single included study for baricitinib, with the commonest fungi being candida [45].

\section{Break point cluster (Bcr) gene-Abelson (Abl) tyrosine kinase (BCR-ABL) inhibitor}

A translocation of genetic material between chromosome 9 and chromosome 22, results in a fusion gene called $B C R$ $A B L 1$. This juxtaposition of BCR favours autophosphorylation of ABL tyrosine kinase, causing persistent activation $[46,47]$. This is turn stimulates a number of survival pathways which are deregulated in many cancers, including PI3K/AKT/ mTOR, RAS/RAF/MEK/ERK, and JAK/STAT. BCR inhibitors block these pathways, reducing cell division and unchecked proliferation, and increasing cell apoptosis (Table 1). Imatinib, the first tyrosine kinase inhibitors targeting BCR-ABL profoundly changed the management of chronic myeloid leukaemia (CML). Second- and thirdgeneration agents are more potent and used both frontline and in patients with disease refractory to imatinib.

By inhibiting haematopoiesis, BCR-ABL inhibitors may suppress the host's cellular immune response and predispose to fungal infections. The impact of altered cell numbers on immune function is not entirely understood. BCR-ABL inhibitors inhibit $\mathrm{T}$ cell proliferation halting at the G0/G1 phase of the cell cycle, in a dose-dependent manner [48-50]. This can occur through off target kinase inhibition $[48,49 \bullet \bullet$. T cell activation is also reported to be compromised [51]. Although the number of NK cells is increased, most studies have found their cytotoxic potential to be decreased [52]. In vitro studies demonstrate suppression of dendritic cell function [53] and reduction in macrophage production of IL- 6 and TNF $\alpha$ in response to TLR stimulation [54].

Despite widespread and long-term use of imatinib, there are few data supporting an association with fungal infections (Table 2). There were only 5 case reports; 2 patients were in haematologic remission and did not demonstrate neutropenia $[50,55]$. The risk of myelosuppression was higher with heavily pretreated patients leading to severe bone marrow aplasia and life-threatening infections [56,57]. Infections with dasatinib were predominantly of bacterial origin, and most often associated with neutropenia. There were few fungal infections in the literature. P. jirovecii pneumonia were reported in 5 patients. Two patients were in haematologic remission, receiving dasatinib for relatively long treatment periods. One of these patient received additional chemotherapy, whilst both were treated with steroids, intensifying the risk for infection [58].

\section{Discussion}

This review has demonstrated the frequency and spectrum of fungal infections with small-molecule protein kinases inhibitors. There has been an unprecedented expansion in the development of therapies that target immune-signalling pathways in malignant and autoimmune diseases. These drugs block essential pathways of antifungal innate and adaptive immunity.

The greatest number of publications on fungal infections with protein kinase inhibitors was identified with ibrutinib, the BTK inhibitor. Infections were often disseminated and presented soon after initiation of therapy. Aspergillus was the most frequently reported fungi. There were a moderate number of infections reported in the literature with the mTOR inhibitors, with $P$. jirovecii as the most frequently reported fungi. The number of infections seen with JAK inhibitors may be overestimated owing to the substantial patient exposure time from postmarketing surveillance analyses. There were fairly few fungal infections reported with agents targeting BCR-ABL, VEGFR, EGFR and ALK, and no publications with agents targeting RET, TRK, CDK, Erb2, ALK, ROCK1/2, FGFR, B-Raf, Fly3 and Syk.

The effects of small-molecule protein kinases inhibitors on the immune system and the associated risk for the development of fungal infections are difficult to predict. This probably relates to a constellation of predisposing factors, implicated in the pathogenesis of fungal infections [14*0]. Certain malignancies like CLL induce a wide range of immune defects that worsen during progression of the underlying disease. The synergistic effects of other immunosuppressive medications including corticosteroids and chemotherapy increase the risk of fungal infections [14••]. The true incidence of infections is likely higher in clinical practice than reported in trials, which recruit patients with fewer comorbid conditions. At higher dose, kinase inhibitors demonstrate off-target effects. For example, tofacitinib selectively inhibits JAK 1 and 3 at the approved dose but becomes a 'pan-JAK' inhibitor at higher doses [59]. Host-related factors might influence drug serum concentrations as these medications undergo hepatic metabolism and renal clearance and are susceptible to drug-drug interactions [14••].

Despites the comparable immune dysfunction of a drug, not all patients are susceptible to fungal infections. This suggests that additional risk factors, specifically a genetic predisposition is important. Polymorphisms have been described in specific immune-related genes, including toll-like receptors (e.g. TLR4) and C-type lectin receptors (e.g. dectin-1) which recognize the fungal structures and initiate inflammatory and antimicrobial host defences. Genetic variants in cytokine 
genes may also contribute to fungal infection vulnerability to fungal infection, including inborn errors in the IL-12/IFN- $\gamma$ axis, promoter polymorphism of IL-10 and defective expression of the TNF receptor [60].

There are challenges in reviewing infectious events across a wide spectrum of therapies. With respect to clinical trials, there is a lack of standardisation across studies as well as variability in reporting practices. Very few of the larger studies reported an incidence rate. First generation medications, that have been licenced for several years will have been investigated across a greater number of trials compared to newer second or third generation agents. Medications that have initial safety signals will also have been examined in greater detail, including large safety data analyses. Similarly, therapies that have been used in clinic practice for several years will have more real-world data that newly licenced drugs. The discrepancy in publication numbers may overestimate the infection risk. A similar effect may be driven by publication bias. The inclusion of conference abstracts may also introduce bias as it is recognised that one fifth of toxicities published in peer-reviewed journals are not reported in the abstract form [61].

In our personal experience, these infections are rare, no matter the underlying exposure. In many cases, it is difficult to ascribe the infection to the kinase inhibitor, the underlying disease, concomitant therapies or whether it is a combination of all three. The profile of fungal infections with JAK inhibitors is similar to that seen with biologics, in particular, antiTNF and anti-IL6 therapy. Although there are no direct comparisons, the spectrum and incidence of fungal infections is similar. Granulomatous infections (histoplasmosis and coccidioidomycosis), PJP and aspergillus are more common. Systemic candida is very rare, with the most invasive infection for the most part being oesophagitis. Considering this information, whilst rare, it is important that clinicians maintain vigilance for fungal disease in people taking small molecule kinase inhibitorsparticularly given the challenges surrounding fungal infection diagnosis.

There is a lack of evidence for antifungal prophylaxis in patients prescribed small-molecule protein kinases inhibitors. There is debate whether the degree of immunosuppression mandates the use of prophylaxis $[43,62]$. For some diseases, patients have received treatment with other agents which have long-lasting immunomodulatory effects contributing to the immunosuppressive state. Current guidelines recommend PJP prophylaxis for patients undergoing certain chemotherapy and antifungal prophylaxis with fluconazole in patients with anticipated neutropenia [63]. It would be prudent to identify high-risk patients through a proactive preemptive approach including routine screening. This approach is already taken for certain infections including tuberculosis and hepatitis. For fungi in which comparable latent states exist, similar screening paradigms could diminish risk of reactivation. Screening for prior exposure should also be proportionate to endemic risk. It is not appropriate to screen all patients; however, in endemic areas, for example Midwest USA, screening for histoplasmosis and coccidioidomycosis may be judicious.

\section{Conclusion}

Small-molecule protein kinases inhibitors predispose to opportunistic fungal infections; however, not all agents demonstrate the same risk. The greatest potential is seen with therapies that target bruton tyrosine kinase, such as ibrutinib. Infections are often disseminated and may present soon after initiation of therapy. The pattern of fungal infection with protein kinases inhibitors fits mechanistically with the specific pathway targeted. However, the drugs pharmacokinetic profile and possibility of off-target kinase inhibition, together with the underlying disease pathology, genetic predisposition for fungal infection and the synergistic effects of other immunosuppressive medications, complicate this picture.

Funding Information K.B. is funded by Medical Research Council as a Clinical Training Research Fellowship (CTRF-MR/R001332/1 to K Bechman)

\section{Compliance with Ethical Standards}

Conflict of Interest James Galloway reports personal fees from the AbbVie, Bristol-Myers Squibb, Celgene, Janssen, Pfizer, and Union Chimique Belge outside the submitted work. Kevin Winthrop reports personal fees from AbbVie, Gilead, Lilly, Pfizer, UCB, Roche, Galapagos, and GSK outside the submitted work. Katie Bechman declares no conflicts of interest relevant to this manuscript.

Human and Animal Rights and Informed Consent This article does not contain any studies with human or animal subjects performed by any of the authors.

Open Access This article is distributed under the terms of the Creative Commons Attribution 4.0 International License (http:// creativecommons.org/licenses/by/4.0/), which permits unrestricted use, distribution, and reproduction in any medium, provided you give appropriate credit to the original author(s) and the source, provide a link to the Creative Commons license, and indicate if changes were made.

\section{References}

Papers of particular interest, published recently, have been highlighted as:

- Of importance

-• Of major importance

1. Limper AH, Adenis A, Le T, Harrison TS. Fungal infections in HIV/AIDS. Lancet Infect Dis. 2017;17:e334-43. https://doi.org/ 10.1016/S1473-3099(17)30303-1. 
2. Wallis RS, Broder M, Wong J, Lee A, Hoq L. Reactivation of latent granulomatous infections by infliximab. Clin Infect Dis. 2005;41(Suppl 3):S194-8. https://doi.org/10.1086/429996.

3. Hohl TM. Immune responses to invasive aspergillosis: new understanding and therapeutic opportunities. Curr Opin Infect Dis. 2017;30:364-71. https://doi.org/10.1097/QCO. 0000000000000381 .

4. Fidel P Jr. Immunity to Candida. Oral Dis. 2002;8:69-75. https:// doi.org/10.1034/j.1601-0825.2002.00015.x.

5. Mengesha BG, Conti HR. The role of IL-17 in protection against mucosal candida infections. J Fungi (Basel). 2017;3:52. https:// doi.org/10.3390/jof3040052.

6. Thompson A, Orr SJ. Emerging IL-12 family cytokines in the fight against fungal infections. Cytokine. 2018;111:398-407. https://doi.org/10.1016/j.cyto.2018.05.019.

7. Roskoski R. A historical overview of protein kinases and their targeted small molecule inhibitors. Pharmacol Res. 2015;100:123. https://doi.org/10.1016/j.phrs.2015.07.010.

8.• Roskoski R. Properties of FDA-approved small molecule protein kinase inhibitors. Pharmacol Res. 2019;144:19-50. https://doi. org/10.1016/j.phrs.2019.03.006 This paper reviews the FDA approved 48 small molecule protein kinase inhibitors including protein kinase structure, mechanism of action and drug indication.

9. Cohen P. Protein kinases - the major drug targets of the twentyfirst century? Nat Rev Drug Discov. 2002;1:309-15. https://doi. org/10.1038/nrd773.

10. Broekman F, Giovannetti E, Peters GJ. Tyrosine kinase inhibitors: multi-targeted or single-targeted? World J Clin Oncol. 2011;2:80 93. https://doi.org/10.5306/wjco.v2.i2.80.

11. Schamroth Pravda M, Schamroth Pravda N, Lishner M. The muddied waters of Ibrutinib therapy. Acta Haematol. 2019;141:20913. https://doi.org/10.1159/000496555.

12. Ping $\mathrm{L}$, et al. The Bruton's tyrosine kinase inhibitor ibrutinib exerts immunomodulatory effects through regulation of tumorinfiltrating macrophages. Oncotarget. 2017;8:39218-29. https:// doi.org/10.18632/oncotarget.16836.

13. Weber ANR, Bittner Z, Liu X, Dang TM, Radsak MP, Brunner C. Bruton's tyrosine kinase: an emerging key player in innate immunity. Front Immunol. 2017 Nov 8;8:1454. https://doi.org/10.3389/ fimmu.2017.01454 ECollection 2017.

14.• Chamilos G, Lionakis MS, Kontoyiannis DP. Call for action: invasive fungal infections associated with ibrutinib and other small molecule kinase inhibitors targeting immune signaling pathways. Clin Infect Dis. 2018;66:140-8. https://doi.org/10.1093/cid/ cix687 This paper identfied predisposing factors associated with an increased risk of fungal infectiosn in patients receiving small molecule kinase inhibitors.

15. Szymczak WA, Davis MJ, Lundy SK, Dufaud C, Olszewski M, Pirofski LA. X-linked immunodeficient mice exhibit enhanced susceptibility to Cryptococcus neoformans infection. MBio. 2013 Jul 2;4(4). pii: e00265-13 doi: https://doi.org/10.1128/ mBio.00265-13.

16. Lionakis MS, et al. Inhibition of B cell receptor signaling by ibrutinib in primary CNS lymphoma. Cancer Cell. 2017;31:833843.e835. https://doi.org/10.1016/j.ccell.2017.04.012.

17. Herbst S, et al. Phagocytosis-dependent activation of a TLR9BTK-calcineurin-NFAT pathway co-ordinates innate immunity to Aspergillus fumigatus. EMBO Mol Med. 2015;7:240-58. https://doi.org/10.15252/emmm.201404556.

18.• Ghez D, et al. Early-onset invasive aspergillosis and other fungal infections in patients treated with ibrutinib. Blood. 2018;131: 1955-9 Large retrospective review of fungal infections with ibrutinib, indicating early-onset of fingal infections and an overrepresentation of invasive aspergillosis.
19. Swan CD, Gottlieb T. Cryptococcus neoformans empyema in a patient receiving ibrutinib for diffuse large B-cell lymphoma and a review of the literature. BMJ Case Rep. 2018;2018:1955-9. https://doi.org/10.1182/blood-2017-11-818286.

20. Messina JA, Maziarz EK, Spec A, Kontoyiannis DP, Perfect JR. Disseminated cryptococcosis with brain involvement in patients with chronic lymphoid malignancies on ibrutinib. Open Forum Infect Dis. 2017;4:ofw261. https://doi.org/10.1093/ofid/ofw261.

21. Ruchlemer R, et al. Ibrutinib: a risk factor for invasive fungal infections? Blood. 2017;130:4323 http://www.bloodjournal.org/ content/130/Suppl_1/4323.

22. Baron M, et al. Fungal infections in patients treated with ibrutinib: two unusual cases of invasive aspergillosis and cryptococcal meningoencephalitis. Leuk Lymphoma. 58:2981-2. https://doi.org/ 10.1080/10428194.2017.1320710.

23.• Rogers KA, et al. Incidence and type of opportunistic infections during ibrutinib treatment at a single academic center. Blood. 2017; 130:830 Large retrospective review of fungal infections indicating independent risk factors for opportunisitc infection.

24. Facchinelli D, Marchesini G, Nadali G, Pagano L. Invasive fungal infections in patients with chronic lymphoproliferative disorders in the era of target drugs. Mediterr J Hematol Infect Dis. 2018;10: e2018063-3. https://doi.org/10.4084/MJHID.2018.063.

25. Ahn IE, Jerussi T, Farooqui M, Tian X, Wiestner A, GeaBanacloche J. Atypical Pneumocystis jirovecii pneumonia in previously untreated patients with CLL on single-agent ibrutinib. Blood. 2016;128:1940-3. https://doi.org/10.1182/blood-201606-722991.

26. Byrd JC, et al. Pooled analysis of safety data from clinical trials evaluating acalabrutinib monotherapy in hematologic malignancies. Blood. 2017;130:4326-6 http://www.bloodjournal.org/ content/130/Suppl_1/4326.

27. Wilson PA, Melville K. Disseminated cryptococcal infection in a patient receiving acalabrutinib for chronic lymphocytic leukemia. Infect Dis Clin Pract. 2019;27:160-2. https://doi.org/10.1097/IPC. 0000000000000722.

28. Xie J, Wang X, Proud CG. mTOR inhibitors in cancer therapy. F1000Res. 2016 Aug 25;5. pii: F1000 Faculty Rev-2078. doi: https://doi.org/10.12688/f1000research.9207.1. ECollection 2016.

29. Geissler EK. The influence of mTOR inhibitors on immunity and the relationship to post-transplant malignancy. Transp Res. 2013;2:S2-2. https://doi.org/10.1186/2047-1440-2-S1-S2.

30.• Thomson AW, Turnquist HR, Raimondi G. Immunoregulatory functions of mTOR inhibition. Nature reviews. Immunology. 2009;9:324-37. https://doi.org/10.1038/nri2546 A review of the mTOR signalling pathway and immunoregularoty functions.

31. Singh N, Heitman J. Antifungal attributes of immunosuppressive agents: new paradigms in management and elucidating the pathophysiologic basis of opportunistic mycoses in organ transplant recipients. Transplantation. 2004;77:795-800. https://doi.org/10. 1097/01.tp.0000117252.75651.d6.

32.• Neff RT, et al. Analysis of USRDS: incidence and risk factors for Pneumocystis jiroveci pneumonia. Transplantation. 2009;88:13541. https://doi.org/10.1097/TP.0b013e3181aad256 Retrospective cohort study of transplant recipients indicating Sirolimus (Rapamycin) associates with development of PCP.

33. Kahan BD, Julian BA, Pescovitz MD, Vanrenterghem Y, Neylan J. Sirolimus reduces the incidence of acute rejection episodes despite lower cyclosporine doses in caucasian recipients of mismatched primary renal allografts: a phase II trial. Rapamune Study Group. Transplantation. 1999;68:1526-32. https://doi.org/ 10.1097/00007890-199911270-00016.

34. Kaymakcalan MD, Je Y, Sonpavde G, Galsky M, Nguyen PL, Heng DYC, et al. Risk of infections in renal cell carcinoma (RCC) and non-RCC patients treated with mammalian target of 
rapamycin inhibitors. Br J Cancer. 2013;108:2478-84. https://doi. org/10.1038/bjc.2013.278.

35. Hu YN, Lee NY, Roan JN, Hsu CH, Luo CY. High-dose calcineurin inhibitor-free everolimus as a maintenance regimen for heart transplantation may be a risk factor for Pneumocystis pneumonia. Transpl Infect Dis. 2017;19. https://doi.org/10.1111/tid.12709.

36.• Villarino AV, Kanno Y, O'Shea JJ. Mechanisms and consequences of Jak-STAT signaling in the immune system. Nat Immunol. 2017;18:374-84. https://doi.org/10.1038/ni.3691 This paper reviews the JAK enzmye family and JAK-STAT pathway, focussing on recent advances in Jak-STAT biology, immune cell function and therapeutic intervention.

37. Scott L, Tofacitinib J. A review of its use in adult patients with rheumatoid arthritis. Drugs. 2013;73:857-74. https://doi.org/10. 1007/s40265-013-0065-8.

38. Clark JD, Flanagan ME, Telliez JB. Discovery and development of Janus kinase (JAK) inhibitors for inflammatory diseases. J Med Chem. 2014;57:5023-38. https://doi.org/10.1021/jm401490p.

39. Chen Y, Gong FY, Li ZJ, Gong Z, Zhou Z, Ma SY, et al. A study on the risk of fungal infection with tofacitinib (CP-690550), a novel oral agent for rheumatoid arthritis. Sci Rep. 2017;7:6779. https://doi.org/10.1038/s41598-017-07261-1.

40. Hardison SE, Herrera G, Young ML, Hole CR, Wozniak KL, Wormley FL Jr. Protective immunity against pulmonary cryptococcosis is associated with STAT1-mediated classical macrophage activation. J Immunol. 2012;189:4060-8. https://doi.org/10.4049/ jimmunol.1103455.

41. Balish E, Wagner RD, Vazquez-Torres A, Pierson C, Warner T. Candidiasis in interferon-gamma knockout (IFN-gamma-/-) mice. J Infect Dis. 1998;178:478-87. https://doi.org/10.1086/ 515645.

42. Dioverti MV, Abu Saleh OM, Tande AJ. Infectious complications in patients on treatment with ruxolitinib: case report and review of the literature. Infect Dis Ther. 2018;50:381-7.

43. Prakash K, Richman D. A case report of disseminated histoplasmosis and concurrent cryptococcal meningitis in a patient treated with ruxolitinib. BMC Infect Dis. 2019;19:287-387. https://doi. org/10.1080/23744235.2017.1390248.

44.• Cohen S, et al. Worldwide, 3-year, post-marketing surveillance experience with tofacitinib in rheumatoid arthritis. Rheumatol Ther. 2018;5:283-91. https://doi.org/10.1007/s40744-018-00973 Large safety analysis of infections with tofacitnib in the treatment of RA.

45.• Winthrop K, L. S, Harigai M, Bradley JD, Chen L, Hyslop DL, et al. Tuberculosis, potential opportunistic infections, and other infections of interest in patients with moderate to severe rheumatoid arthritis in the baricitinib program [abstract]. Arthritis Rheumatol. 2017, 2017;69(suppl 10) Large safety analysis of infections with baricitinib in the treatment of RA.

46.• Cilloni D, Saglio G. Molecular pathways: BCR-ABL. Clin Cancer Res. 2012;18:930-7. https://doi.org/10.1158/1078-0432.CCR-101613 This paper reviews the deregulated tyrosine kinase activity of BCR-ABL, the molecular pathways involved and clinical translational advances.

47. Holyoake TL, Helgason GV. Do we need more drugs for chronic myeloid leukemia? Immunol Rev. 2015;263:106-23. https://doi. org/10.1111/imr. 12234 .

48. Seggewiss R, et al. Imatinib inhibits T-cell receptor-mediated Tcell proliferation and activation in a dose-dependent manner. Blood. 2005;105:2473-9. https://doi.org/10.1182/blood-200407-2527.

49.• Al-Ameri A, et al. Opportunistic infections are uncommon with dasatinib in patients with chronic myeloid leukemia in chronic phase (CML-CP). Blood. 2009;114:1120-0 A safety analysis eporting the frequency of opportunistic infections including fungal in clinical trials of dasatinib in CML.
50. Speletas M, Vyzantiadis TA, Kalala F, Plastiras D, Kokoviadou K, Antoniadis A, et al. Pneumonia caused by Candida krusei and Candida glabrata in a patient with chronic myeloid leukemia receiving imatinib mesylate treatment. Med Mycol. 2008;46:25963. https://doi.org/10.1080/13693780701558969.

51. Sillaber C, Herrmann H, Bennett K, Rix U, Baumgartner C, Böhm $\mathrm{A}$, et al. Immunosuppression and atypical infections in CML patients treated with dasatinib at $140 \mathrm{mg}$ daily. Eur J Clin Investig. 2009;39:1098-109. https://doi.org/10.1111/j.1365-2362.2009. 02206 .

52. Salih J, Hilpert J, Placke T, Grünebach F, Steinle A, Salih HR, et al. The BCR/ABL-inhibitors imatinib, nilotinib and dasatinib differentially affect NK cell reactivity. Int J Cancer. 2010;127: 2119-28. https://doi.org/10.1002/ijc.25233.

53. Appel S, Boehmler AM, Grünebach F, Müller MR, Rupf A, Weck $\mathrm{MM}$, et al. Imatinib mesylate affects the development and function of dendritic cells generated from CD34\&1t;sup\&gt;+\&lt;/sup\&gt; peripheral blood progenitor cells. Blood. 2004;103:538-44. https://doi.org/10.1182/blood-2003-03-0975.

54. Knoll BM, Seiter K. Infections in patients on BCR-ABL tyrosine kinase inhibitor therapy: cases and review of the literature. Infection. 2018;46:409-18. https://doi.org/10.1007/s15010-0171105-1.

55. Nasir T, Lee C, Lawrence AS, Brown JS. Invasive aspergillosis complicating treatment with tyrosine kinase inhibitors. BMJ Case Rep. 2019;12:e226121. https://doi.org/10.1136/bcr-2018-226121.

56. Lokeshwar N, Kumar L, Kumari M. Severe bone marrow aplasia following imatinib mesylate in a patient with chronic myelogenous leukemia. Leuk Lymphoma. 2005;46:781-4. https://doi.org/ 10.1080/10428190500046778.

57. Crisan AM, Ghiaur A, Stancioaca MC, Bardas A, Ghita C, Manea $\mathrm{CM}$, et al. Mucormycosis during imatinib treatment: case report. J Med Life. 2015;8:365-70.

58. Chang H, Hung Y-S, Chou W-C. Pneumocystis jiroveci pneumonia in patients receiving dasatinib treatment. Int $\mathrm{J}$ Infect Dis. 2014;25:165-7. https://doi.org/10.1016/j.ijid.2014.04.030.

59. O'Shea JJ, Kontzias A, Yamaoka K, Tanaka Y, Laurence A. Janus kinase inhibitors in autoimmune diseases. Ann Rheum Dis. 2013;72(Suppl 2):ii111-5.

60. Cunha C, Aversa F, Bistoni G, Casagrande A, Rodrigues F, Romani L, et al. Immunogenetic profiling to predict risk of invasive fungal diseases: where are we now? Immunol Investig. 2011;40:723-34. https://doi.org/10.3109/08820139.2011. 586395.

61. Vera-Badillo FE, et al. Bias in reporting of randomised clinical trials in oncology. Eur J Cancer (Oxford, England : 1990). 2016;61:29-35. https://doi.org/10.1016/j.ejca.2016.03.066.

62. Heine A, Brossart P, Wolf D. Ruxolitinib is a potent immunosuppressive compound: is it time for anti-infective prophylaxis? Blood. 2013;122:3843-4. https://doi.org/10.1182/blood-201310-531103.

63. Varughese T, et al. Serious infections in patients receiving ibrutinib for treatment of lymphoid cancer. Clin Infect Dis. 2018;67:687-92. https://doi.org/10.1093/cid/ciy175.

64. Zaytseva YY, Valentino JD, Gulhati P, Mark Evers B. mTOR inhibitors in cancer therapy. Cancer Lett. 2012;319:1-7. https:// doi.org/10.1016/j.canlet.2012.01.005.

65. Hodge JA, et al. The mechanism of action of tofacitinib - an oral Janus kinase inhibitor for the treatment of rheumatoid arthritis. Clin Exp Rheumatol. 2016;34:318-28.

66. O'Shea JJ, Schwartz DM, Villarino AV, Gadina M, McInnes IB, Laurence A. The JAK-STAT pathway: impact on human disease and therapeutic intervention. Annu Rev Med. 2015;66:311-28. https://doi.org/10.1146/annurev-med-051113-024537.

67. Gambillara E, Laffitte E, Widmer N, Decosterd LA, Duchosal MA, Kovacsovics T, et al. Severe pustular eruption associated 
with imatinib and voriconazole in a patient with chronic myeloid leukemia. Dermatology. 2005;211:363-5. https://doi.org/10.1159/ 000088510.

68. Rodriguez GH, Ahmed SI, Al-akhrass F, Rallapalli V, Safdar A. Characteristics of, and risk factors for, infections in patients with cancer treated with dasatinib and a brief review of other complications. Leuk Lymphoma. 2012;53:1530-5. https://doi.org/10. 3109/10428194.2012.656626.

69. Al-Ameri AM, Cortes JE, Kantarjian H, Burton E, Quintas Cardama A, Jabbour E, et al. Infectious events in patients with chronic myeloid leukemia treated with Nilotinib as a front line therapy and after Imatinib failure. Blood. 2010;116(21):1233. https://doi.org/10.1182/blood.V116.21.1233.1233.

70. Couturier M-A, et al. Blinatumomab + ponatinib for relapsed Ph1positive acute lymphoblastic leukemia: the French experience. Blood. 2018;132:4014. https://doi.org/10.1182/blood-2018-99111546.

71. Nadali G, et al. Infections in patients with lymphoproliferative diseases treated with target therapy. Italian Multicentric Retrospective Study Seifem 2017. Blood. 2018;132:4164. https://doi.org/10.1182/blood-2018-99-111518.

72. Duma N, et al. Invasive aspergillosis in chronic lymphocytic leukemia: therapy and outcomes. Blood. 2017;130:4327.

73. Chaul Barbosa C, DeAngelis LM, Grommes C. Ibrutinib associated infections: a retrospective study. J Clin Oncol. 2017;35: e19020-0. https://doi.org/10.1200/JCO.2017.35.15_suppl. e19020.

74. Protin C, Paricaud K, Despas F, Martin-Blondel G, Ysebaert L. Risk factors and profile of infections on ibrutinib therapy outside clinical trials: a single center experience of 68 patients (conference abstract). EHA Library Protin C. Jun 9, 2016; 132624; E1075 Haematologica. Conference: 21st Congress of the European Hematology Association. Denmark. 101 (Supplement 1) (pp 443), 2016. Date of Publication: June 2016. (2016). https:// library.ehaweb.org/eha/2016/21st/132624/caroline.protin.risk. factors.and.profile.of.infections.on.ibrutinib.therapy.html? $\mathrm{f}=\mathrm{m} 1$

75. Autore F, et al. Risk of infectious complications in patients with chronic lymphocytic leukemia in the era of BCR inhibitors: a retrospective single institution experience. Blood. 2018;132: 5552. https://doi.org/10.1182/blood-2018-99-119654.

76. Tillman BF, Pauff JM, Satyanarayana G, Talbott M, Warner JL. Systematic review of infectious events with the Bruton tyrosine kinase inhibitor ibrutinib in the treatment of hematologic malignancies. Eur J Haematol. 2018;100:325-34. https://doi.org/10. 1111/ejh.13020.

77. Beresford R, Dolot V, Foo H. Cranial aspergillosis in a patient receiving ibrutinib for chronic lymphocytic leukemia. Med Mycol Case Rep. 2019;24:27-9. https://doi.org/10.1016/j.mmcr. 2019.02.005.

78. Faisal MS, Shaikh H, Khattab A, Albrethsen M, Fazal S. Cerebral aspergillosis in a patient on ibrutinib therapy-a predisposition not to overlook. J Oncol Pharm Pract. 2019 Sep;25(6):1486-90. https://doi.org/10.1177/1078155218788717.

79. Park J. Pulmonary aspergillosis secondary to Ibrutinib use. Chest. 2015;148:104A. https://doi.org/10.1378/chest.2279372.

80. McCarter SJ, Vijayvargiya P, Sidana S, Nault AM, Lane CE, Lehman JS, et al. A case of ibrutinib-associated aspergillosis presenting with central nervous system, myocardial, pulmonary, intramuscular, and subcutaneous abscesses. Leuk Lymphoma. 2019;60:559-61. https://doi.org/10.1080/10428194.2018. 1494271.

81. Abid MB, Stromich J, Gundacker ND. Is ibrutinib associated with disseminated cryptococcosis with CNS involvement? Cancer Biol Ther. 2019;20(2):138-40. https://doi.org/10.1080/15384047. 2018.1508622
82. Okamoto K, Proia LA, Demarais PL. Disseminated cryptococcal disease in a patient with chronic lymphocytic leukemia on Ibrutinib. Case Rep Infect Dis. 2016;2016:4642831-3. https:// doi.org/10.1155/2016/4642831.

83. Stankowicz M, Banaszynski M, Crawford R. Cryptococcal infections in two patients receiving ibrutinib therapy for chronic lymphocytic leukemia. J Oncol Pharm Pract. 2019;25:710-4. https:// doi.org/10.1177/1078155217752078.

84. Pouvaret A, Guery R, Montillet M, Molina TJ, Duréault A, Bougnoux ME, et al. Concurrent cerebral aspergillosis and abdominal mucormycosis during ibrutinib therapy for chronic lymphocytic leukaemia. Clin Microbiol Infect. 2019;25:771-3. https://doi.org/10.1016/j.cmi.2019.01.016.

85. Koehler AB, Vijayvargiya P, Ding W. Probable invasive pulmonary cryptococcosis and possible Cryptococcal empyema in CLL treated with frontline Ibrutinib. Mayo Clin Proc. 2019;94:915-7. https://doi.org/10.1016/j.mayocp.2019.02.002.

86. Kreiniz N, Bejar J, Polliack A, Tadmor T. Severe pneumonia associated with ibrutinib monotherapy for CLL and lymphoma. Hematol Oncol. 2018;36:349-54. https://doi.org/10.1002/hon. 2387.

87. Marini G, Bertizzolo ML, Castelli G, Cattelan A, Girolami B, Zambello R, Zola E, Baggio G. Invasive candidiasis in B-cell chronic lymphocytic leukemia: an example of internal medicine complexity. Italian Journal of Medicine. Conference: 21st Congresso Nazionale della Societa Scientifica FADOI. Italy. 10 (Supplement 2) (pp 73), 2016. Date of Publication: 01 May 2016. [Conference Abstract] http://www.italjmed.org/index.php/ijm/ article/view/itjm.2016.s2/858

88. Serota DP, Mehta AK, Phadke VK. Invasive fungal sinusitis due to mucor species in a patient on Ibrutinib. Clin Infect Dis. 2018;66: 1482-3. https://doi.org/10.1093/cid/cix1058.

89. Stein MK, et al. Cutaneous mucormycosis following a bullous pemphigoid flare in a chronic lymphocytic leukemia patient on ibrutinib. World J Oncol. 2018;9:62-5. https://doi.org/10.14740/ wjon1099w.

90. Figueroa Castro CE. Id: 54: cutaneous mucormycosis in a patient with chronic lymphocytic leukemia: a pharmacological dilemma. J Investig Med. 2016;64:956-95957. https://doi.org/10.1136/jim2016-000120.93.

91. Sylvine P, Thomas S, Pirayeh E, The French network of regional pharmacovigilance, C. Infections associated with ruxolitinib: study in the French pharmacovigilance database. Ann Hematol. 2018;97:913-4. https://doi.org/10.1007/s00277-018-3242-8.

92. Polverelli N, Palumbo GA, Binotto G, Abruzzese E, Benevolo G, Bergamaschi M, et al. Epidemiology, outcome, and risk factors for infectious complications in myelofibrosis patients receiving ruxolitinib: a multicenter study on 446 patients. Hematol Oncol. 2018;36:561-9. https://doi.org/10.1002/hon.2509.

93. Torti L, Morelli A, Bacci F, Di Bartolomeo P. Infectious events in a cohort of patients with myelofibrosis under treatment comparing ruxolitinib with conventional therapy. A monocentric experience of 22 patients retrospectively analysed. Haematologica. Conference: 22th Congress of the European Hematology Association. Spain. 102 (Supplement 2) (pp 818-819), 2017. Date of Publication: June 2017. [Conference Abstract] https:// doi.org/10.3324/haematol.2016.155390.

94. Chen C-C, Chen Y-Y, Huang C-E. Cryptococcal meningoencephalitis associated with the long-term use of ruxolitinib. Ann Hematol. 2016;95:361-2. https://doi.org/10.1007/s00277-0152532-7.

95. Chakrabarti A, Sood N. Cryptococcal meningitis in an immunocompetent patient with primary myelofibrosis on long-term ruxolitinib: report of a rare case and review of literature Magazine of European Medical Oncology. 2018;11(4):348-50. https://doi.org/10.1007/s12254-018-0435-8. 
96. Hirano A, et al. Pulmonary cryptococcosis in a ruxolitinib-treated patient with primary myelofibrosis. Respir Med Case Rep. 2017;22:87-90. https://doi.org/10.1016/j.rmcr.2017.06.015.

97. Wysham NG, Sullivan DR, Allada G. An opportunistic infection associated with ruxolitinib, a novel Janus kinase 1,2 inhibitor. Chest. 2013;143:1478-9. https://doi.org/10.1378/chest.12-1604.

98. Liu J, Mouhayar E, Tarrand JJ, Kontoyiannis DP. Fulminant Cryptococcus neoformans infection with fatal pericardial tamponade in a patient with chronic myelomonocytic leukaemia who was treated with ruxolitinib: case report and review of fungal pericarditis. Mycoses. 2018;61:245-55. https://doi.org/10.1111/ myc. 12735 .

99. Chan JF, et al. Disseminated infections with Talaromyces marneffei in non-AIDS patients given monoclonal antibodies against CD20 and kinase inhibitors. Emerg Infect Dis. 2015;21: 1101-6. https://doi.org/10.3201/eid2107.150138.

100. Fleischmann R, Wollenhaupt J, Takiya L, Maniccia A, Kwok K, Wang L, et al. Safety and maintenance of response for tofacitinib monotherapy and combination therapy in rheumatoid arthritis: an analysis of pooled data from open-label long-term extension studies. RMD Open. 2017;3:e000491. https://doi.org/10.1136/ rmdopen-2017-000491.

101. Sarker S, et al. Su1874 - Histoplasmosis in the setting of biologic therapy: a tertiary care inflammatory bowel disease experience. Gastroenterology. 152:S579. https://doi.org/10.1016/S00165085(17)32090-5(2017).

102. Saber LT, Ikeda MY, Almeida JM. Posttransplantation conversion to sirolimus-based immunosuppression: a single center experience. Transplant Proc. 2007;39:3098-100. https://doi.org/10. 1016/j.transproceed.2007.04.021.

103. Leet AS, Bergin PJ, Richardson M, Taylor AJ, Esmore D, Kaye DM. Outcomes following de novo CNI-free immunosuppression after heart transplantation: a single-center experience. Am J Transplant Off J Am Soc Transplant Am Soc Transplant Surg. 2009;9:140-8. https://doi.org/10.1111/j.1600-6143.2008.02456. $\mathrm{x}$.

104. Schaffellner S, Wagner D, Jakoby E, Kniepeiss D, Iberer F. Efficacy and safetey of sirolimus after liver transplantation. Transplant international. Conference: 16th congress of the European Society for Organ Transplantation, ESOT. Vienna Austria. Conference Publication: (var.pagings). 26 (SUPPL. 2) (pp 200), 2013. Date of Publication: November 2013. [Conference Abstract] https://doi.org/10.1111/tri.12214.

105. Dominguez J, Mahalati K, Kiberd B, McAlister VC, MacDonald AS. Conversion to rapamycin immunosuppression in renal transplant recipients: report of an initial experience. Transplantation. 2000;70:1244-7.

106. Saur SJ, Peter S, Sonnichsen K, Metzler G, Faul C, Schaller M, Bethge WA, Vogel W, Kanz L, Haen SP. Infections with Fusarium species in patients with hematological malignancies-immediate treatment required. j. Conference: Jahrestagung der Deutschen, Osterreichischen und Schweizerischen Gesellschaften fur Hamatologie und Medizinische Onkologie 2014. Hamburg Germany. Conference Publication: (var.pagings). 37 (SUPPL. 5) (pp 159), 2014. Date of Publication: October 2014. [Conference Abstract] https://doi.org/10.1159/000368945.

107. Iijima $\mathrm{Y}$, et al. Invasive pulmonary aspergillosis mimicking organizing pneumonia after mTOR inhibitor therapy: a case report. Int
J Infect Dis. 2018;69:75-7. https://doi.org/10.1016/j.ijid.2018.01. 033.

108. Tanaka Y, et al. Spontaneous resolution of Pneumocystis jirovecii pneumonia on high-resolution computed tomography in a patient with renal cell carcinoma. Am J Case Rep. 2014;15:496-500. https://doi.org/10.12659/AJCR.890947.

109. M., O. F. B. Z. G. M. M. G. H. Experience with mTOR inhibitors in pediatric liver transplantation (Conference Abstract). Transplantation. Conference: 26th International Congress of the Transplantation Society, TTS 2016. Hong Kong. 100 (7 Supplement 1) (pp S354), 2016. Date of Publication: July 2016. (2016).

110. King C, Clement S, Katugaha S, Brown AW Fungal thyroiditis in a lung transplant recipient Case Reports 2018;2018:bcr-2018227033. https://doi.org/10.1136/bcr-2018-227033.

111. Angermeier S, Leimer L, Aulitzky WE. Pneumocystis pneumonia associated with everolimus treatment. Onkologie. Conference: Jahrestagung der Deutschen, Osterreichischen und Schweizerischen Gesellschaften fur Hamatologie und Onkologie 2013. Wien Austria. Conference Publication: (var.pagings). 36 (SUPPL. 7) (pp 11), 2013. Date of Publication: October 2013. [Conference Abstract] https://www.karger.com/Article/Pdf/ 356365.

112. Saito Y, Nagayama M, Miura Y, Ogushi S, Suzuki Y, Noro R, et al. A case of Pneumocystis pneumonia associated with everolimus therapy for renal cell carcinoma. Jpn J Clin Oncol. 2013;43:55962. https://doi.org/10.1093/jjco/hyt019.

113. Carbonnaux M, Molin Y, Souquet PJ, Tantin A, Lombard-Bohas $\mathrm{C}$, Walter T. Pneumocystis jirovecii pneumonia under everolimus in two patients with metastatic pancreatic neuroendocrine tumors. Investig New Drugs. 2014;32:1308-10. https://doi.org/10.1007/ s10637-014-0150-1.

114. Chen KH, Weng MT, Chou YH, Lu YF, Hsieh CH. Epigastric distress caused by esophageal candidiasis in 2 patients who received sorafenib plus radiotherapy for hepatocellular carcinoma: case report. Medicine. 2016;95:e3133. https://doi.org/10.1097/ md.0000000000003133.

115. Visvardis EE, Gao F, Paes MN, Duprez O, Waxman J. Lung aspergillosis in renal cell carcinoma patient treated with sunitinib. QJM. 2012;105:689-92. https://doi.org/10.1093/qjmed/hcr091.

116. Kim YW, Lee HW, Cho J, Choi HS, Lee J, Park SS, et al. Conversion of aspergilloma to chronic necrotizing pulmonary aspergillosis following treatment with sunitinib: a case report. Oncol Lett. 2016;12:3472-4. https://doi.org/10.3892/ol.2016.5052.

117. Park S, Park S, Choi H, Park JY, Lim HS, Park MJ, et al. Invasive pulmonary aspergillosis in a patient with metastatic non-small cell lung cancer after treatment with gefitinib. Korean J Intern Med. 2018;33:211-3. https://doi.org/10.3904/kjim.2015.276.

118. Deiana L, Grisanti S, Ferrari V, Tironi A, Brugnoli G, Ferrari L, et al. Aspergillosis superinfection as a cause of death of crizotinibinduced interstitial lung disease successfully treated with highdose corticosteroid therapy. Case Rep Oncol. 2015;8:169-73. https://doi.org/10.1159/000381209.

Publisher's Note Springer Nature remains neutral with regard to jurisdictional claims in published maps and institutional affiliations. 